The reason for the regression of the subcutaneous tumours induced in rabbits by Zilber ${ }^{16}$ may be due to the difference in the strain of the RSV used. This was not so in the case of Ahlström's experiments ${ }^{17}$, for he noted regression of the fibrosarcoma-like lesions of the rabbits using the Schmidt-Ruppin strain of RSV. Using the latter strain we obtained a malignant progression of the induced neoplasia which led to the death of the host. To explain these different results, it is possible that the large doses of virus used in our work may not be the only reason. The choice of the brain as a target organ may be of some importance. The induction of malignant neoplasms by RSV in rabbits has not previously been roported. Brain tumours havo not been induced in this host by any virus. The use of these large animals, carrying a primary malig. nant tumour, should be of interest in cancer research.

Giancarlo F. Rabotti

Richard L. Sellers

Wirtiley A. Anderson

Laboratory of Viral Careinogenesis, National Cancer Institute,

National Institutes of Hoalth, Bethesda, Maryland.

${ }^{1}$ Sehmidt-Ruppin, K. H., Sonderbande zur Strahlentherapie, 41, 3, 25 (1950). 'Svet-Moldavsky, G. J., Nature, 180, 1290 (1957).

${ }^{3}$ Zilber, L. A., and Kryukova, I. N., Voprosi Virusologii, 4, 239 (1957).

" Svet-Moldavsky, G. J., Nature, 182, 1452 (1958).

- Svoboda, J., and Grozdanovic, J., Folia Biol. (Prague), 5, 46 (1959).

'Munroe, J. D., and Southam, C. M., J. Nat. Cancer Inst., 32, 501 (1964).

'Ahlström, C. G., and Forsby, N., J. Exp. Med., 115, 839 (1962).

${ }^{8}$ Rabotti, G. F., and Raine, W. A., Nature, 204, 898 (1964).

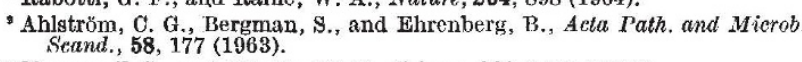

${ }^{10}$ Munroe, S. S., and Windle, W. F., Seience, 140, 1415 (1963).

$"$ "Bryan, R. W., J. Nat. Cancer Inst., 16, 843 (1956).

${ }_{12}$ Harris, R. J. C., Proc. Roy. Soc., 13.146, 59 (1956)

${ }^{13}$ Rabotti, G. F., Raine, W. A., and Sellers, R. L., Science, 147, 504 (1965). ${ }^{14}$ Rabotti, G. F., Anderson, W. R., and Sellers, R. L., Nature, 206, 946 (1965). ${ }^{15}$ Zilber, L. A., Voprosi Virusologii, 3, $166(1958)$.

${ }_{26}$ Zilber, L. A., J. Nat. Cancer Inst., 26, 1295 (1961).

${ }^{12}$ Ahlström, C. G., Bergman, S., Forsby, N., and Jonsson, N., Acta Union Intern. Contre Cancer, 19, 204 (1903).

${ }^{18}$ Moloney, J. B., J. Nat. Caneer Inst., 16, 877 (1956).

\section{Retardation of Parasitaemia, Prolongation of Life or Survival of Lactating Mice in Infections with Trypanosoma cruzi}

KRAMPITZ ${ }^{1}$ found an endogenous synchronization of the propagation of host and parasite in Trypanosoma duttoni infections of mice. Experimental infections with $T$. duttoni at certain periods of pregnancy have resulted in an exceedingly intense and prolonged parasitaemia in mice.

Mice infected with $T$. cruzi have also shown an increase in the number of parasites during pregnancy; however, the increase was only slight compared with that in female control animals.

Lactating mice, however, display a very peculiar behaviour. Developmont of the parasites is retarded in them; the mice live longer or survive. When given a dosage of $1 \cdot 3 \times 10^{6}$ trypanosomes per mouse immediatoly following birth, the life of the animals is found to be about one-third longer than that of normal mice. Infection on the tenth day after birth significantly increases the timo of survival. When extromely high doses of trypanosomes $\left(1.3 \times 10^{6}\right)$ wero administered, one-tenth of the lactating mice survived. Lower doses of trypanosomes (nnmely $700 \times 10^{3}$ to $\left.250 \times 10^{3}\right)$, which would be fatal for normal mice, produce similar conditions. Here, it can be expected that up to one-half the lactating animals will survive. The results are well confirmed statistically.

White fernale mice, 3-4 months old (nulliparac), of the weight class $33-35 \mathrm{~g}$ of the strain $N M R$ 1/Tübingen were used for our cxperiments, as well as trypanosomes of the strain WBH (T. cruzi, Wellcome Brazil-Hamburg $)^{2}$, which had been kept for approximately 1 year by mouse passages. All injections of parasites were given intra muscularly, The mouse litter was constantly adjusted to 10. Parasites obtained from venous tail blood were counted daily in a Thoma haemocytometer. Approximately 250 animals have been used so far in the experiments, which were frequently repeated. The number of mice in the various experimental groups was always kept the same (10) in order to comply with the statistical basis of the experiments.

Further experiments are being undertaken at present, in particular to clarify the cause of these strange phenomena. Therapeutical implications cannot be excluded.

Institut für Infektions- und

H. E. Krampitz

Tropenmedizin der Universität, 8 München 9.

${ }^{1}$ Krampitz, H. E., First Intern. Congr. Parasit., Rome, 1964 (in the press). ${ }^{2}$ Ifauschka, T. S., et al., Amer. J. Trop. Med., 30, 1 (1950).

\section{RADIOBIOLOGY}

\section{Plasma Concentration and Excretion of Calcium-47, Strontium-85, Barium-133 and Radium-223 following Successive Intravenous Doses to a Healthy Man}

SEveral investigations have been made of the turnover of radioactive calcium and strontium in man. Qualitatively their metabolism is similar, as is to be expected from their close chemical relationship, but quantitative data reveal biological discriminations which occur in certain organs. Corresponding similarities and discriminations in the turnover of barium and radium have been investigated, but experimental data refer almost entirely to laboratory animals.

In the present investigation, a healthy adult male, sixty years old, was given not only barium and radium but also calcium and strontium so that the motabolism. of all four alkaline earths could be compared in the same individual. By this means, biological variation between different individuals was eliminated. Each radioactivo isotope was given intravenously on a separate occasion (Table 1), but all four were administered within a 10 -week period to minimize any possible temporal changes in turnover. The present preliminary report gives the results for the plasma concentration and excretion following the four successivo intravenous injections of the separate radioactive isotopes.

A weighed portion from a solution of the respective carrier-free radioactive solution was made up to $10 \mathrm{ml}$. in isotonic saline. $4 \mathrm{ml}$, of a sterile solution were injected into the antecubital vein of the right arm and the remainder was used for the preparation of radioactive standards. Urine and faocos were collected and serial $20-\mathrm{ml}$. blood samples were taken by veni-puncture from the left arm at $10 \mathrm{~min}, 3$ and $12 \mathrm{~h}$ and about $1,2,4,6$ and 8 days after each intravenous dose.

For ${ }^{47} \mathrm{Ca},{ }^{85} \mathrm{Sr}$ and ${ }^{133} \mathrm{Ba}$, the $\gamma$-ray intensity in the principal photopeak ('Table 1) was measured with a scintillation $\gamma$-ray spectromoter by comparing the counting-rate in the peak with that from a standard solution. In the case of ${ }^{22} \mathrm{Ra}$, the method of assay for solutions of faecal ash was essentially tho same, but in samples of low activity, for example, in plasma, the total $\alpha$-particle activity in a chomically separated fraction was compared with that from a standard.

The results obtained for the plasma concentrations of the separato radionuclides up to 8 days after injection are

\begin{tabular}{|c|c|c|c|c|c|c|}
\hline Isotope & $\begin{array}{l}\text { Half- } \\
\text { life }\end{array}$ & $\begin{array}{c}\text { Radiation } \\
\text { exnitted }\end{array}$ & $\begin{array}{l}\text { Prino } \\
\text { energy } \\
\text { (MeV) }\end{array}$ & $\begin{array}{l}\text { abal } \gamma \text {-ray } \\
\text { abundance } \\
(\%)\end{array}$ & $\begin{array}{l}\text { Intravenous } \\
\text { dose }(\mu \mathrm{c} .)\end{array}$ & $\begin{array}{c}\text { Date of } \\
\text { injection }\end{array}$ \\
\hline $\begin{array}{l}{ }^{47} \mathrm{Ca} \\
{ }^{86} \mathrm{Sr} \\
{ }^{13}{ }^{3} \mathrm{Ba} \\
{ }^{223} \mathrm{Ra} \text { and } \\
\text { daughter }\end{array}$ & $\begin{array}{c}4 \cdot 7 \mathrm{~d} \\
65 \cdot 0 \mathrm{~d} \\
7 \cdot 5 \mathrm{y} \\
11 \cdot 7 \mathrm{~d}\end{array}$ & $\begin{array}{r}\beta-\gamma \\
\gamma \\
\gamma \\
\alpha \beta-\gamma\end{array}$ & $\begin{array}{l}1 \cdot 81 \\
0.51 \\
0.36 \\
0.27\end{array}$ & $\begin{array}{r}77 \\
100 \\
70 \\
\sim 20\end{array}$ & $\begin{array}{l}1 \cdot 94 \\
0 \cdot 54 \\
2 \cdot 25 \\
0 \cdot 72\end{array}$ & $\begin{array}{r}26.2 .65 \\
9.2 .65 \\
12.1 .65 \\
23.3 .65\end{array}$ \\
\hline
\end{tabular}

